\section{Is vasoproliferative tumour (reactive retinal glioangiosis) part of the spectrum of proliferative vitreoretinopathy?}

\begin{abstract}
Objectives To investigate the involvement of retinal pigment epithelial (RPE) cells in reactive retinal glioangiosis (RRG; known also as retinal vasoproliferative tumour or massive retinal gliosis).
\end{abstract}

Methods Nine RRG lesions (six in enucleated eyes and three endoresection specimens) were studied employing histological methods. Eight of the nine lesions were also subjected to immunohistochemical evaluation of glial and RPE cell content.

Results All lesions consisted of masses within the sensory retina that contained glial cells, abnormal blood vessels, and scattered melanin pigment. Epi- and subretinal membranes were also observed in association with the RRG lesions in all six enucleated eyes (retinal surfaces could not be examined in endoresection specimens).

Immunohistochemistry revealed RPE cells in seven of eight RRG lesions and in the associated periretinal membranes. These RPE cells were typically fibroblastic or macrophage-like in phenotype and, within RRG lesions, often perivascular in location. Glia represented the majority of cells in the retinal masses.

Conclusions The findings indicate that RPE cells may be involved in RRG.

The observations engender speculation that RRG represents a part of the spectrum of proliferative vitreoretinopathy, in which case therapies designed to counter proliferative vitreoretinopathy might also have a role in the management of RRG.

Eye (2009) 23, 1851-1858; doi:10.1038/eye.2008.351; published online 14 November 2008

\author{
P Hiscott ${ }^{1,2,3}$ and $\mathrm{H}$ Mudhar $^{4}$
}

Keywords: vasoproliferative tumour; massive retinal gliosis; reactive retinal glioangiosis; retinal pigment epithelial cells; RPE; cytokeratin

\section{Introduction}

Over the past decade, the term vasoproliferative tumours of the ocular fundus or retina has been applied to focal or diffuse vascularised retinal lesions that have such features as peripheral location, haemorrhage and/or exudation, and yellow-red or peach colouration. ${ }^{1}$ Conversely, the label massive retinal gliosis has long been used for segmental or diffuse retinal disorders in which the retina is thickened and replaced by glial tissue. ${ }^{2}$ Recently, several authors have pointed out that retinal vasoproliferative tumours and massive retinal gliosis have common microscopic appearances. ${ }^{3-5}$ For example, both abnormalities contain masses of glial cells, which replace the neuroretina, as well as anomalous blood vessels with characteristics such as hyalinisation and thrombosis. ${ }^{3-5}$ Indeed, these observations suggest that the two conditions are synonymous, perhaps differing only in the prominence of the glial or vascular component, and the name reactive (or reactionary) retinal glioangiosis is proposed instead of vasoproliferative tumour or massive retinal gliosis. ${ }^{3-5}$

The term reactive retinal glioangiosis (RRG) emphasises the notion that these lesions are thought to be reactive and not neoplastic in nature, as well as the principal tissues involved. In addition to glial cells, reactive retinal diseases typically involve retinal pigment epithelial (RPE) cells. RPE cells in such situations tend to leave their normal monolayer, and the sequestrated cells exhibit a wide range of
${ }^{1}$ Unit of Ophthalmology, School of Clinical Sciences, University of Liverpool, Liverpool, UK

${ }^{2}$ St Paul's Eye Unit, Royal Liverpool University Hospital, Liverpool, UK

${ }^{3}$ Department of Pathology, Royal Liverpool University Hospital, Liverpool, UK

${ }^{4}$ Department of Histopathology, Royal Hallamshire Hospital, Sheffield, UK

Correspondence: P Hiscott, Unit of Ophthalmology, School of Clinical Sciences, Duncan Building, Daulby Street, Liverpool L69 3GA, UK

Tel: +44 151706 4912;

Fax: +44 1517065802 .

E-mail: paulsh@liv.ac.uk

Received: 1 May 2008 Accepted in revised form: 21 October 2008 Published online: 14 November 2008 
metaplastic (transdifferentiated) forms including fibroblastic, macrophagic, cuboidal (layer), osseous, and pseudoadenomatous (tubuloacinar) phenotypes. ${ }^{6,7}$ Although there is reference in a number of reports to pigmentary changes adjacent to or 'beneath' RRG abnormalities, and even suggestions of a possible role of RPE proliferation in the vascularisation process, no studies have directly evaluated the contribution of RPE to these lesions. ${ }^{1,3,4,8,9}$ This dearth of study may partly reflect the difficulties of identifying metaplastic RPE in tissues, as the cells tend to release melanin in addition to the dramatic change in phenotype during transdifferentiation. ${ }^{10}$ Nevertheless, such an investigation is justified as it may provide corroborative evidence of the reactive nature of RRG and help to further elucidate its pathobiology.

Lately, we have shown that an immunohistochemical assessment of a spectrum of cytokeratins, a family of intermediate filament proteins retained by RPE cells during metaplasia, can help detect and localise transdifferentiated RPE cells in tissues from patients with various retinal diseases. ${ }^{11-13}$ Therefore, employing similar methodology, we studied the distribution of RPE cells, including metaplastic forms, in a series of RRG lesions.

\section{Materials and methods}

A retrospective systematic review of all archival specimens was undertaken with a diagnosis of vasoproliferative tumour or of massive retinal gliosis at the National Specialist Ophthalmic Pathology Service in Liverpool and Sheffield. This review yielded a total of nine specimens, six of which were enucleated eyes (Figure 1). The remaining three specimens were endoresections. Clinical details concerning all nine specimens are provided in Table 1 . The study had local research ethics committee approval.

All specimens had been fixed in $10 \%$ neutral buffered formalin, dehydrated in ascending concentrations of alcohol and embedded in paraffin wax. Sections 4-6 $4 \mathrm{~m}$ thick of wax-embedded tissue were evaluated by routine histopathological and immunohistochemical light microscopic methods as described previously. ${ }^{14}$ Briefly, sections were stained with haematoxylin and eosin, with periodic acid-Schiff (PAS) method or with Perls' method for ferric ions. Further sections were stained with an immunohistochemical technique to delineate glial and
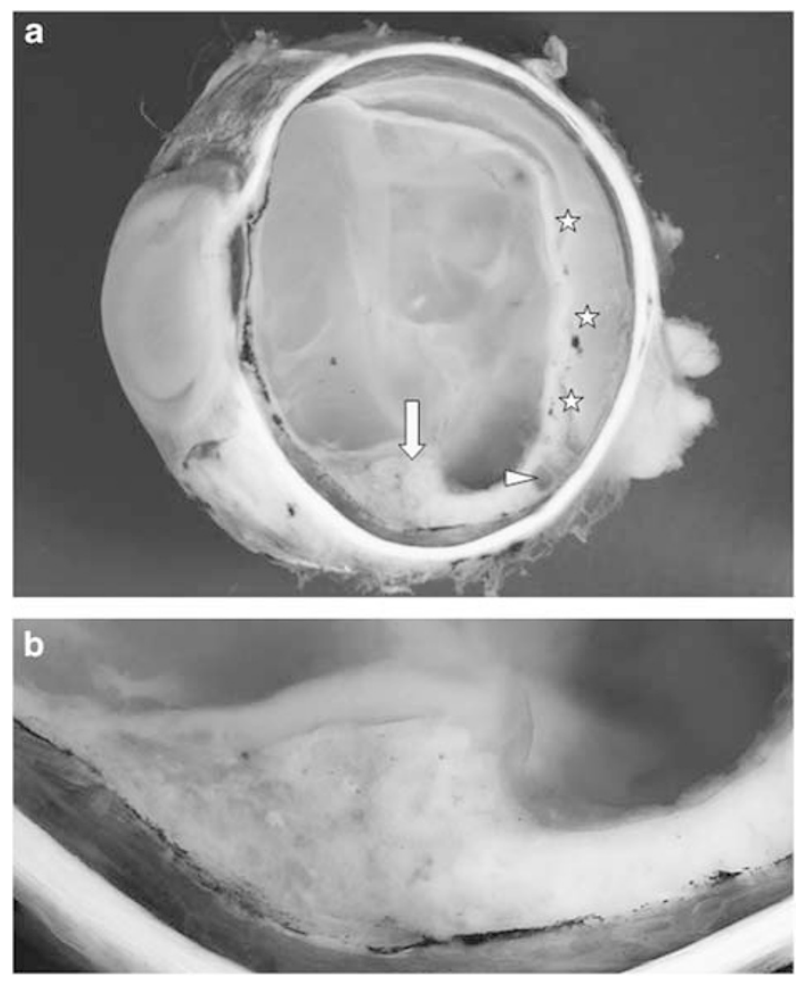

Figure 1 (a and b) Macro images of a reactive retinal glioangiosis (RRG) lesion in an enucleated eye. (a) The RRG can be seen in the peripheral retinal (arrow). Posteriorly, the retina is detached with subretinal exudate $\left.{ }^{*}\right)$. Retinal pseudocystic change is also seen (arrowhead). (b) Higher power image of RRG itself.

Table 1 Clinical details of the nine reactive retinal glioangiosis lesions

\begin{tabular}{llllll}
\hline Specimen number & Specimen type & Side & Gender & Age & Aetiology/ocular history $^{\mathrm{a}}$ \\
\hline 1 & Eye & $\mathrm{L}$ & $\mathrm{F}$ & 70 & RRD \\
2 & Eye & $\mathrm{L}$ & $\mathrm{F}$ & 43 & Trauma/Cataract \\
3 & Eye & $\mathrm{R}$ & $\mathrm{F}$ & 45 & Idiopathic/congenital cataract \\
4 & Eye & $\mathrm{L}$ & $\mathrm{F}$ & 27 & Penetrating trauma \\
5 & Eye & $\mathrm{R}$ & $\mathrm{M}$ & 52 & Amblyopia \\
6 & Eye & $\mathrm{L}$ & $\mathrm{F}$ & 67 & Idiopathic $^{\mathrm{a}}$ \\
7 & Endoresection & $\mathrm{L}$ & $\mathrm{M}$ & 28 & Squint surgery/amblyopia $^{\text {a }}$ \\
8 & Endoresection & $\mathrm{R}$ & $\mathrm{F}$ & 34 & Idiopathic \\
9 & Endoresection & $\mathrm{R}$ & $\mathrm{F}$ & 20 & Idiopathic \\
\hline
\end{tabular}

Abbreviations: $\mathrm{F}=$ female; $\mathrm{L}=$ left eye; $\mathrm{M}=$ male; $\mathrm{R}=$ right eye; $\mathrm{RRD}=$ rhegmatogenous retinal detachment.

a Disease duration was unknown in all specimens except for number 6 where the duration was approximately 9 years. 

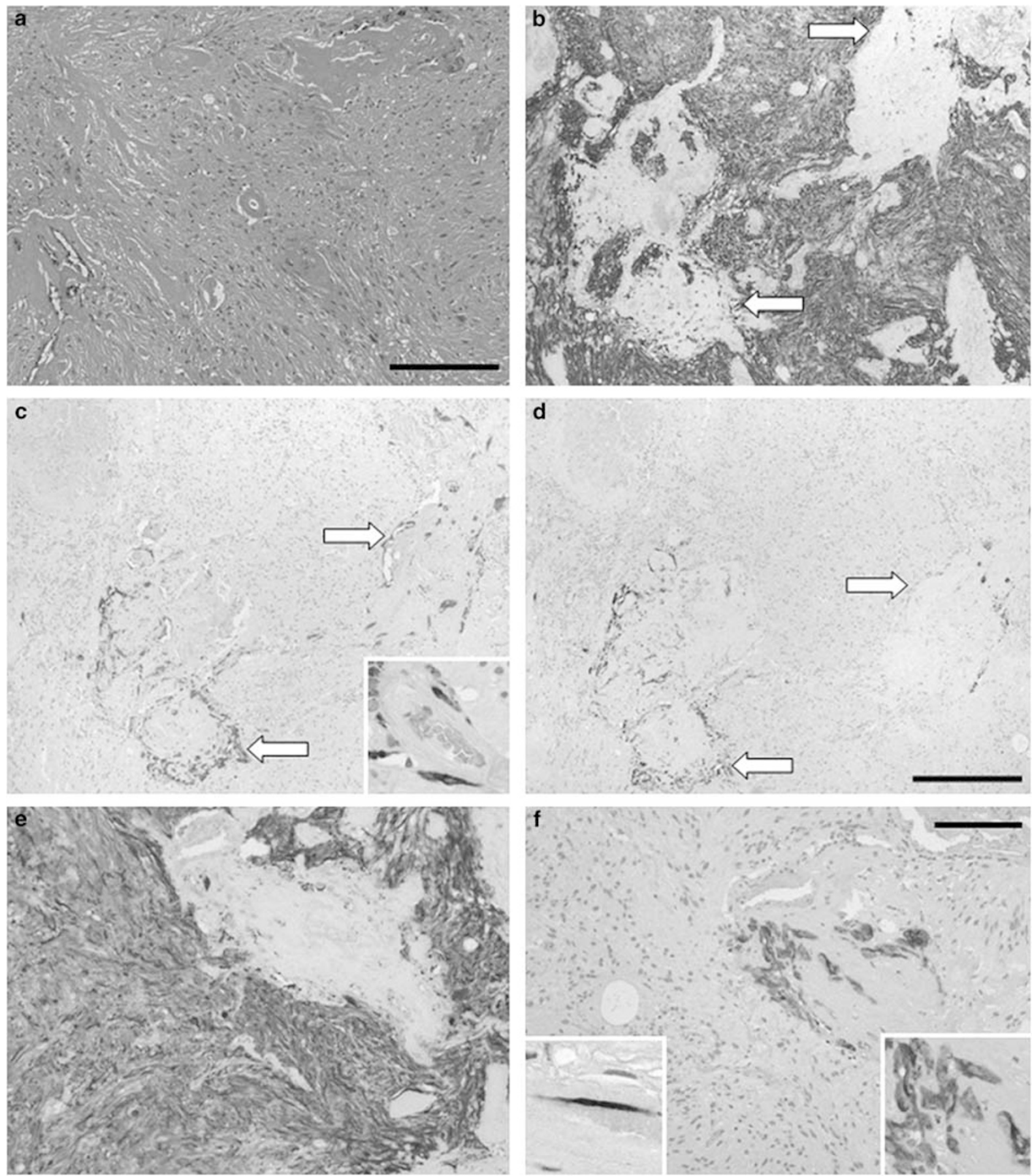

Figure 2 Photomicrographs from sections through a RRG. (a) Staining with haematoxylin and eosin reveals a mass of eosinophilic spindle-shaped glial cells with abnormal blood vessels and patchy pigmentation. (b-f). Sections stained with the immunoperoxidase technique (red chromogen, haematoxylin counter stain) for GFAP (b and e), cytokeratin 7 (c and f, including insets) and CAM5.2 (cytokeratins 8/18; d). Panels b-d show the same area of the lesion. (b) GFAP staining confirms the glial origin of most of the cells. However, there are also RPE cells that lie in areas with scattered pigment and which are immunoreactive for cytokeratin 7 (c) but not cytokeratins 8/18 (d; arrows). (c) Higher magnification shows (inset) fibroblastic RPE cells adjacent to a thick-walled blood vessel in the lesion. Panels e and $f$ show another area of the same lesion. GFAP staining again reveals the predominance of glial cells in the tissue (e), but cytokeratin 7 staining (f) discloses a cluster of fibroblastic RPE cells in association with (paravascular) fibrosis. The kite and spindle shape of these RPE cells can be appreciated when they are viewed at higher magnification (right-hand inset). Fibroblastic RPE cells are also present in fibrous tissue of the RRG-related subretinal membrane (left-hand inset). Scale bars: $\mathrm{a}=200 \mu \mathrm{m}$; $\mathrm{d}=500 \mu \mathrm{m}$; $\mathrm{f}=200 \mu \mathrm{m}$. 

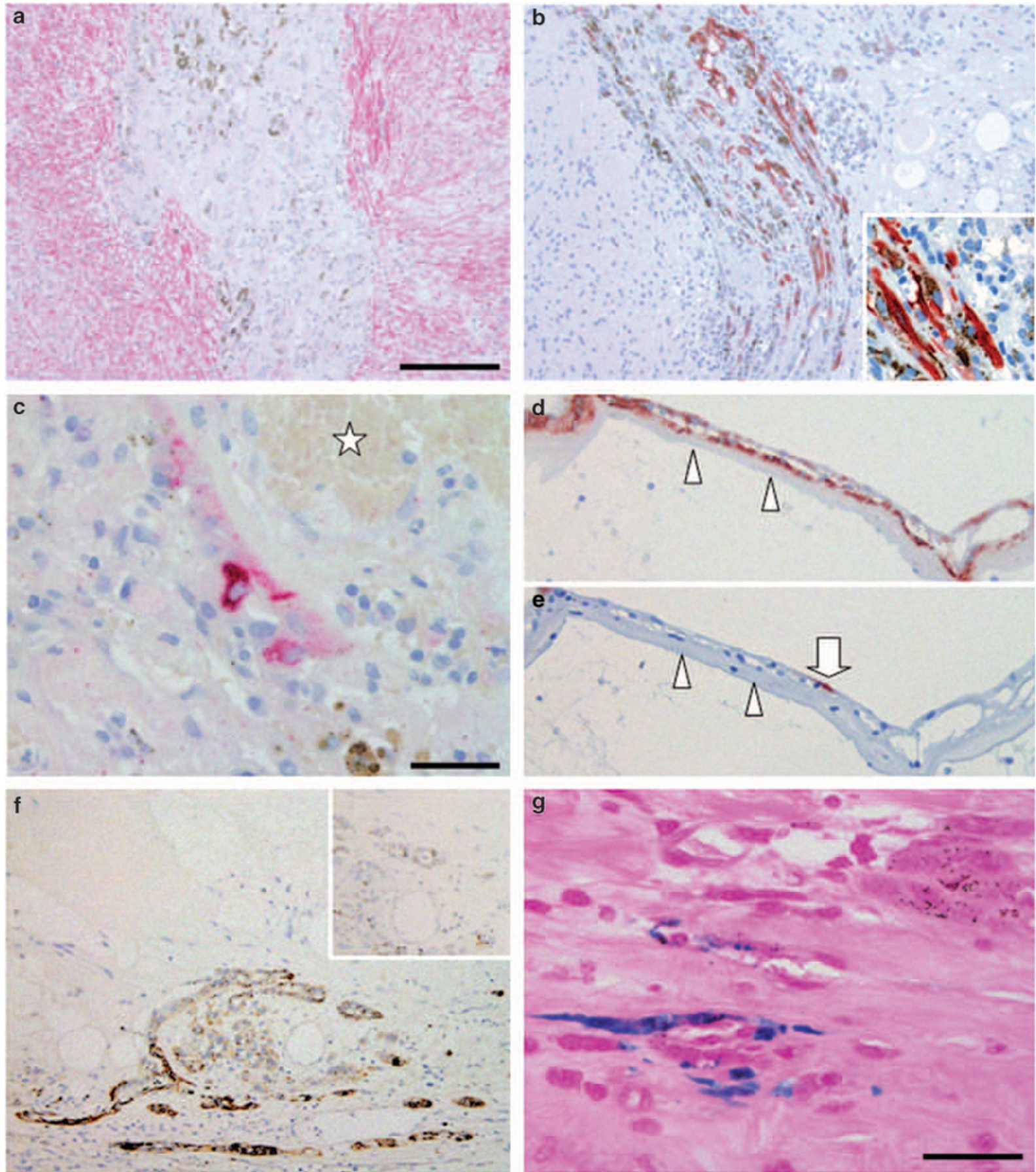

Figure 3 (a-c) Sections through RRG lesions stained by the immunohistochemical method (pink chromogen, haematoxylin counter stain) for GFAP (a), cytokeratin 7 (b), and cytokeratins (MNF116: c). Panels a and b show the same area of the same lesion in which glial cells abound (a), but numerous RPE cells are present within a pigmented, more fibrous part of the tissue. Panel $b$ shows (inset) the spindle shape of the RPE cells at higher power. (c) Another specimen in which an irregular layer of cuboidal RPE cells is seen adjacent to a vessel $(*)$. Again, melanin is present nearby. ( $\mathrm{d}$ and e) An epiretinal membrane overlying a cystic part of an RRG mass-the internal limiting membrane of the retinal surface is marked (arrowheads). In panel d, glial cells have been labelled red, whereas in panel e, RPE cells have been so labelled (immunoperoxidase, red chromogen, haematoxylin counter stain); glial cells predominate, but RPE cells are also present (arrow). (f and g) Subretinal membranes from two different RRG lesions. Panel $f$ has been labelled for cytokeratins 8/18 to reveal a tubuloacinar RPE cell arrangement. The inset is another section from the same RRG area stained for cytokeratin 7: the cells do not express this subtype of cytokeratin, although their pigment is apparent (both immunoperoxidase, brown chromogen, haematoxylin counter stain). The section in panel $\mathrm{g}$ has been stained with Perls' method to reveal iron of presumed blood origin (blue) as well as melanin pigment. Scale bars: $\mathrm{a}=200 \mu \mathrm{m} ; \mathrm{c}=50 \mu \mathrm{m} ; \mathrm{g}=50 \mu \mathrm{m}$. 

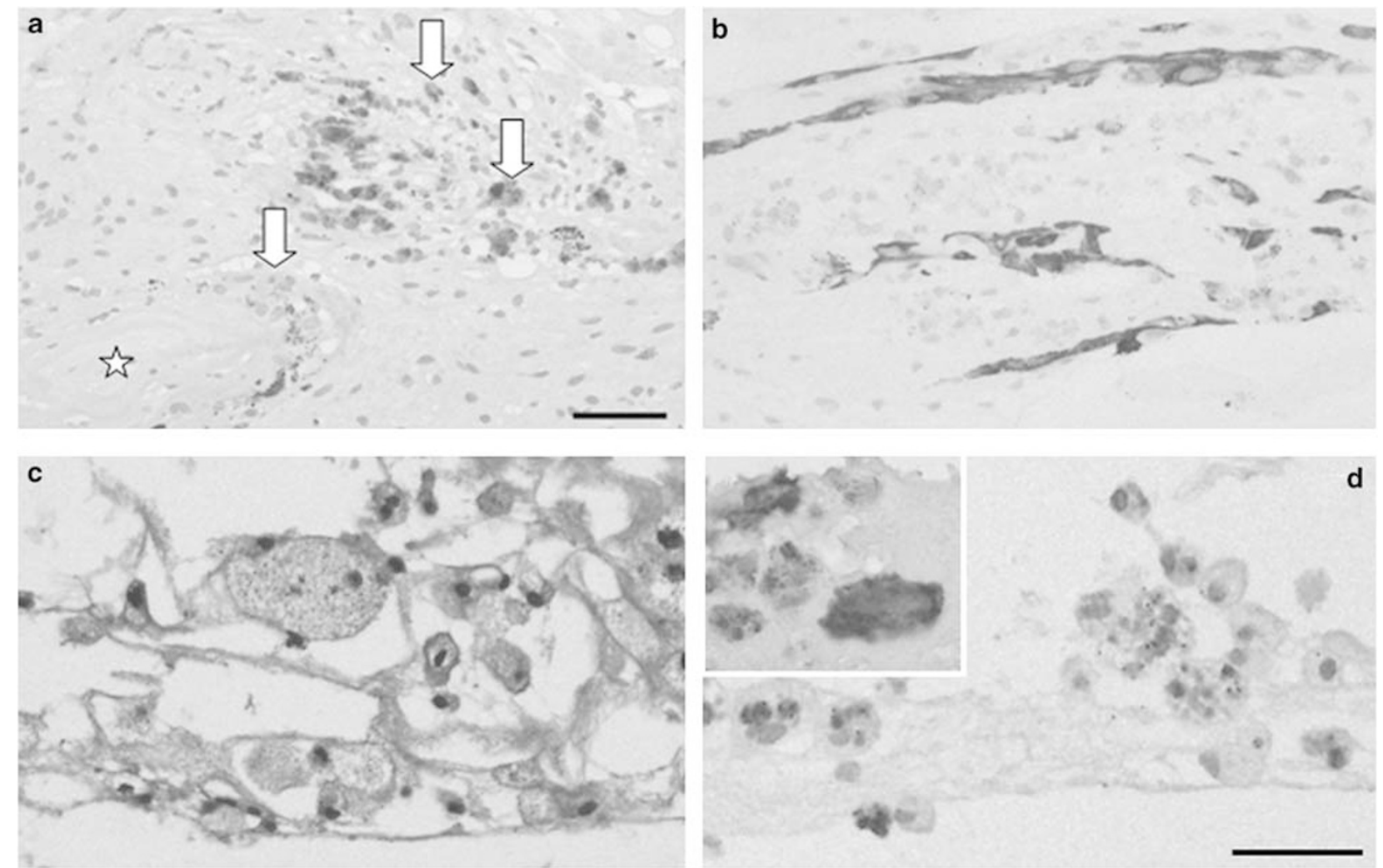

Figure 4 (a and b) Sections through an RRG lesion stained by the immunohistochemical method (red chromogen, haematoxylin counter stain) for cytokeratins (MNF116; a) and cytokeratin 7 (b). In panel a, scattered, isolated macrophage-like RPE cells are present (arrows) around a small focus of RPE cells and near a thick-walled vessel (*), whereas in (b), a prominent aggregate of fibroblastic RPE cells are seen elsewhere in the lesion. (c and d) Photomicrographs of the subretinal membrane associated with the same specimen as depicted in panels a and b. (c) Staining with haematoxylin and eosin reveals distended granular macrophage-like cells in the tissue. (d) Immunohistochemistry for cytokeratins (MNF116) shows a negative reaction for this antibody, whereas, some of the cells (inset) do label for cytokeratin 7 (both immunoperoxidase, red chromogen, haematoxylin counter stain). Scale bars: $\mathrm{a}=100 \mu \mathrm{m} ; \mathrm{d}=50 \mu \mathrm{m}$.

retinal pigment epithelium (RPE) cells in the tissue. ${ }^{14}$ Glial cells were detected using a monoclonal antibody to glial fibrillary acidic protein (GFAP), whereas RPEs were identified employing the panel of monoclonal cytokeratin antibodies CAM 5.2, MNF116, and CK7 (all antibodies were from Dako, Ely, UK) that between them recognised cytokeratins $5,6,7,8,17,18$, and $19 .{ }^{15}$ Immunoreactive sites were visualised red/pink (using 3-amino-9-ethylcarbazole or fast red) or brown (with diaminobenzidine tetrahydrochloride). Controls were conducted as described previously. ${ }^{14}$

Immunohistochemically stained sections were counterstained with Mayer's haematoxylin.

\section{Results}

All specimens exhibited histological features typical of RRG, namely a proliferation of spindle-shaped GFAPpositive glial cells with abnormal vessels (Figures 2-4). Vascular anomalies included mural hyalinisation and fibrosis. There were also epiretinal and subretinal membranes in all six enucleated specimens (Table 2; the retinal surfaces could not be inspected in the endoresection tissue). The epiretinal membranes extended posteriorly over retina not involved by the RRG mass and anteriorly over the pars plana of the ciliary body. The subretinal membranes were subjacent to the RRG masses. Scattered, generally scanty, pigment was observed in the RRG masses and in the periretinal membranes, being most prominent in subretinal membranes (Figures 2-4). Generally, pigment was melanin in origin, but some iron-containing pigment (presumed haemosiderin) was also present (Figure 3).

One of the (globe) specimens had insufficient lesion tissue for full immunohistochemical evaluation and thus was not investigated with antibodies to cytokeratins. Of the remaining eight RRG lesions, seven contained RPE cells as judged by immunoreactivity for cytokeratins (Table 2; Figures 2-4). RPE cells represented a minority of the cells $(1-5 \%)$ in all these seven lesions, glial cells being 
Table 2 Histopathological findings in the nine reactive retinal glioangiosis lesions

\begin{tabular}{llcccc}
\hline $\begin{array}{l}\text { Specimen } \\
\text { number }\end{array}$ & $\begin{array}{l}\text { RPE in RRG } \\
\text { mass (phenotype) }\end{array}$ & $\begin{array}{l}\text { Subretinal } \\
\text { membrane }\end{array}$ & $\begin{array}{l}\text { RPE in SRM } \\
\text { (phenotype) }\end{array}$ & $\begin{array}{l}\text { Epiretinal } \\
\text { membrane }\end{array}$ & $\begin{array}{l}\text { RPE in ERM } \\
\text { (phenotype) }\end{array}$ \\
\hline 1 & $+(\mathrm{F}, \mathrm{C}, \mathrm{M})$ & + & $+(\mathrm{F}, \mathrm{C}, \mathrm{M}, \mathrm{A})$ & + & $+(\mathrm{F})$ \\
2 & $+(\mathrm{F}, \mathrm{C}, \mathrm{M}, \mathrm{A})$ & + & $+(\mathrm{F}, \mathrm{C}, \mathrm{M}, \mathrm{A}, \mathrm{O})$ & + & $+(\mathrm{F})$ \\
3 & $+(\mathrm{F}, \mathrm{C}, \mathrm{M})$ & + & $+(\mathrm{F}, \mathrm{C}, \mathrm{A}, \mathrm{O})$ & + & $+(\mathrm{C})$ \\
4 & $\mathrm{~N} / \mathrm{A}$ & + & $\mathrm{N} / \mathrm{A}^{\mathrm{a}}$ & + & $+(\mathrm{F})$ \\
5 & $+(\mathrm{F}, \mathrm{M})$ & + & $+(\mathrm{F}, \mathrm{C}, \mathrm{A}, \mathrm{O})$ & + & $+(\mathrm{F})$ \\
6 & - & + & $\mathrm{I}, \mathrm{I}, \mathrm{A})$ & $\mathrm{I}$ & $\mathrm{I}$ \\
7 & $+(\mathrm{F}, \mathrm{C}, \mathrm{M})$ & $\mathrm{I}$ & $\mathrm{I}$ & $\mathrm{I}$ & $\mathrm{I}$ \\
8 & $+(\mathrm{F}, \mathrm{C}, \mathrm{M})$ & $\mathrm{I}$ & $\mathrm{I}$ & $\mathrm{I}$
\end{tabular}

Abbreviations: $+=$ present; $-=$ absent; $\mathrm{I}=$ indeterminate (endoresection tissue only); N/A = insufficient tissue for immunohistochemical analysis; $\mathrm{RPE}=$ retinal pigment epithelial cells; $\mathrm{RRG}=$ reactive retinal glioangiosis; $\mathrm{SRM}=$ subretinal membrane 'beneath' $\mathrm{RRG}$; $\mathrm{ERM}=\mathrm{epiretinal} \mathrm{membrane}$ 'over' RRG.

RPE phenotypes: F, fibroblast-like (mesenchymal transdifferentiation); C, cuboidal phenotype (monolayer); A, pseudoadenomatous (tubuloacinar); $\mathrm{M}$, macrophage-like; $\mathrm{O}$, osseous metaplasia.

${ }^{\mathrm{a} C}$ Contains pseudoadenomatous pigmented cells.

the most abundant cell type. Fibroblast-like (spindle- or kite-shaped) and macrophage-like (isolated, often vacuolated, round- or oval-shaped) were the most common RPE phenotypes encountered respectively, both types being present in all seven specimens (Table 2; Figures 2-4). Cuboidal RPE cells in small irregular layers were observed in five RRGs, and a pseudoadenomatous (tubuloacinar) RPE cell arrangement was found in one lesion. The cytokeratin subtype expressed by the cells varied between and within lesions. In general, and as reported previously, ${ }^{11}$ cytokeratin 7 was particularly expressed by fibroblastic RPE cells, whereas RPE in layers tended to express other cytokeratins (Figures 2-4).

RPE cells in RRG had a propensity to be distributed adjacent to or near vessels, or within fibrous tissue (which itself was apt to be paravascular; Figures 2-4). Melanin was often noted in these locations as well (Figures 2 and 3). Nevertheless, isolated RPE cells, or small RPE aggregates, were also found elsewhere in RRG lesions (Figure 4).

The RRG-associated periretinal membranes could be fully analysed with the immunohistochemical antibody panel in five of the six enucleated eyes. All five of these specimens had RPE cells in both epi- and subretinal membranes, including the one RRG in which RPE cells could not be found in the 'main' lesion (Table 2; Figures 3 and 4). In epiretinal membranes, the RPE cells were usually fibroblastic, whereas in subretinal membranes, the cells exhibited a much wider range of phenotypes (Table 2; Figures 3 and 4).

\section{Discussion}

Using immunohistochemistry with a combination of anticytokeratin antibodies, we have shown that RPE cells, including metaplastic cells, are components of the RRG process. Indeed, the cells were detected in all but one of the eight RRG lesions available for complete immunohistochemical evaluation, although it was clear that they were not as abundant as glia. Nevertheless, RPE cells could be found scattered throughout the lesions and in particular in the vicinity of blood vessels. The latter observation is in keeping with a report of perivascular pigment proliferation in a postretinal detachment RRG, and may reflect the tendency of RPE cells to migrate to sites of retinal haemorrhage or vasculature in established retinal pathologies, such as retinitis pigmentosa. ${ }^{2,8,13}$ The finding also explains why many RRG lesions contain melanin, which has presumably been released by the incoming RPE cells. Moreover, as in their involvement in other retinal pathologies, RPE cells in RRG exhibit a wide range of phenotypes, the most prominent of which are fibroblastic forms. These 'mesenchymally transdifferentiated' cells are capable of collagen production, and thus could contribute to the (fibrous) material accumulating around vasculature. Furthermore, as RPE cells are capable of synthesising a wide variety of factors that modulate matrix and cellular activities, ${ }^{16}$ it is possible that the cells could play a role in orchestrating RRG development.

RRGs are typically peripheral lesions, and although some are so large as to fill much of the posterior segment, ${ }^{17}$ in our study they tended to abut the ora serrata (Figure 1). Furthermore, membranes on the retinal surface (epiretinal membranes) of the RRGs extended over the ora serrata and pars plana epithelium towards the pars plicata. Epiretinal membranes also extended posteriorly from the RRG to partly 'cover' otherwise uninvolved retina. By contrast, subretinal proliferations (subretinal membranes) were more 
restricted in their distribution, usually lying subjacent to the RRG lesion itself.

The relationship between RRG and epiretinal and subretinal membranes is well documented. ${ }^{18,19}$ Consistent with this affiliation, we found that, in the enucleated eyes in which the retinal surfaces could be assessed, all the RRG lesions in this study were associated with epiretinal and subretinal membranes. We were also able to show that these periretinal membranes contained cells of RPE origin. RPE cell containing periretinal membranes are the hallmark of the disease known as proliferative vitreoretinopathy (PVR). PVR is a complication of retinal detachment and it is notable that many RRG lesions are associated with prior retinal detachment or conditions that give rise to retinal detachment. ${ }^{1,3,5,8,19-23}$ Furthermore, it is known that there is a component of PVR that is within the sensory retina itself (intraretinal PVR; iPVR) and that, as in the main RRG lesions, is characterised by gliosis with a smaller RPE component. ${ }^{24}$ Gross distortion of gliotic retina with folding associated with periretinal membrane can produce a localised mass, ${ }^{10}$ and vascular proliferation is also recognised in PVR. ${ }^{25}$ Therefore, taken together, the results of our and earlier studies indicate that RRG and PVR have many pathobiological features in common and lead us to speculate that RRG is, in reality, a part of the spectrum of PVR or, perhaps more accurately, as RRG has a variety of aetiologies, PVR-type reactions. This notion is also consistent with the concept that RRG is a reactive process, ${ }^{1,3-5}$ rather than representing a benign neoplasm as suggested previously. ${ }^{21,26}$ However, many RRG lesions appear to be idiopathic (primary) in origin. ${ }^{1}$ At present, it remains unclear as to what could trigger a PVR-like reaction in such patients.

A better understanding of the biology of these lesions may lead to further therapeutic measures to conserve the eye. In the past, many eyes with RRG were enucleated. More recently, a variety of eye-conserving treatment approaches have been employed or suggested in the management of RRG. ${ }^{27}$ If RRG is part of the PVR spectrum, therapies designed to counter PVR might be added to the list of potential treatments for this condition.

\section{Acknowledgements}

We wish to acknowledge the help of Dr Sarah Coupland with this study. Archival specimens were from patients who were under the care of Professor BE Damato, Mr SK Gibran, Professor IG Rennie or Professor D Wong. Wendy Prime and Andrea Caine provided technical assistance.

\section{References}

1 Shields CL, Shields JA, Barrett J, De Potter P. Vasoproliferative tumours of the ocular fundus.
Classification and clinical manifestations in 103 patients. Arch Ophthalmol 1995; 113(5): 615-623.

2 Yanoff M, Fine BS. Ocular pathology: a text and atlas. Publisher: Harper and Row: Hagerstown, 1975, pp 447-455.

3 Heimann H, Bornfeld N, Vij O, Coupland SE, Bechrakis NE, Kellner $\mathrm{U}$ et al. Vasoproliferative tumours of the retina. Br J Ophthalmol 2000; 84(10): 1162-1169.

4 Irvine F, O'Donnell N, Kemp E, Lee WR. Retinal vasoproliferative tumours: surgical management and histological findings. Arch Ophthalmol 2000; 118(4): 563-569.

5 Gelisken F, Inhoffen W, Rohrbach JM, Bartz-Schmidt KU. Massive retinal gliosis: a late complication of retinal detachment surgery. Graefes Arch Clin Exp Ophthalmol 2004; 242(3): 255-258.

6 Machemer R, Laqua H. Pigment epithelium proliferation in retinal detachment (massive periretinal proliferation). Am J Ophthalmol 1975; 80(1): 1-23.

7 Machemer R. Pathogenesis and classification of massive periretinal proliferation. Br J Ophthalmol 1978; 62(11): 737-747.

8 Henkind P, Morgan G. Peripheral retinal angioma with exudative retinopathy in adults (coats's lesion). $\mathrm{Br} J$ Ophthalmol 1966; 50(1): 2-11.

9 Jain K, Berger AR, Yucil YH, McGowan HD. Vasoproliferative tumours of the retina. Eye 2003; 17(3): 364-368.

10 Hiscott $\mathrm{P}$, Sheridan C. The retinal pigment epithelium, epiretinal membranes and proliferative vitreoretinopathy. In: Marmor MF, Wolfensberger TJ (eds). Retinal Pigment Epithelium-Function and Disease. Oxford University Press: New York „, 1998, pp 478-491.

11 Sheridan C, Hiscott P, Grierson I. Retinal pigment epithelium: differentiation and dedifferentiation. In: Kirchhof B, Wong D (eds). Vitreo-retinal surgery. Essentials in Ophthalmology. Springer: Berlin, 2005, pp 101-119.

12 Guerin EP, Wong D, Silvestri G, Hiscott P. Cytokeratin subtyping to distinguish reactive and neoplastic RPE cells. Br J Ophthalmol 2006; 90(6): 801-802.

13 Gibran SK, Kenawy N, Wong D, Hiscott P. Changes in the retinal inner limiting membrane associated with Valsalva retinopathy. Br J Ophthalmol 2007; 91(5): 701-702.

14 Sheridan CM, Rice D, Hiscott P, Wong D, Kent DL. The presence of AC133-positive cells suggests a possible role of endothelial progenitor cells in the formation of choroidal neovascularization. Invest Ophthalmol Vis Sci 2006; 47(4): 1642-1645.

15 McKechnie NM, Boulton M, Robey HL, Savage FJ, Grierson I. The cytoskeletal elements of human retinal pigment epithelium: in vitro and in vivo. J Cell Sci 1988; 91(2): 303-312.

16 Hiscott P, Sheridan C, Magee R, Grierson I. Matrix and the retinal pigment epithelium in proliferative retinal disease. Prog Retinal Eye Res 1999; 18(2): 167-190.

17 Inayama Y, Hanashi M, Yazawa T, Mitsui H, Kimura A, Ito D. Massive gliosis of the retina: report of a case investigated by immunohistochemistry and clonality assays. Hum Pathol 2005; 36(6): 702-705.

18 Baines PS, Hiscott P, McLeod D. Posterior non-vascularised proliferative extraretinopathy and peripheral nodular retinal telangiectasis. Trans Ophthalmol Soc UK 1982; 102(4): 487-491. 
19 Gray RH, Gregor ZJ. Acquired peripheral retinal telangiectasia after retinal surgery. Retina 1994; 14(1): 10-13.

20 Gottlieb F, Fammartino JJ, Stratford TP, Brockhurst RJ. Retinal angiomatous mass. A complication of retinal detachment surgery. Retina 1984; 4(3): 152-157.

21 Campochiaro PA, Conway BP. Hemangiomalike masses of the retina. Arch Ophthalmol 1988; 106(10): 1409-1413.

22 Tranos P, Clare G, Sullivan P. Vasoproliferative tumour of the retina after spontaneous reattachment of rhegmatogenous retinal detachment. Retina 2006; 26(4): 475-476.

23 Windisch-Furrer R, Kurz-Levin MM, Sutter FK, Reineke T, Helbig H. Vasoproliferative retinal tumours. Klin Monatsbl Augenheilkd 2007; 224(4): 364-366.
24 Pastor JC, Méndez CM, de la Fuente MA, Coco RM, GarcíaArumí J, de la Rúa ER et al. Intraretinal immunohistochemistry findings in proliferative vitreoretinopathy with retinal shortening. Ophthalmic Res 2006; 38(4): 193-200.

25 Morino I, Hiscott P, McKechnie N, Grierson I. Variation in epiretinal membrane components with clinical duration of the proliferative tissue. $\mathrm{Br}$ J Ophthalmol 1990; 74(7): 393-399.

26 Shields JA, Decker WL, Sanborn GE, Augsburger JJ, Goldberg RE. Presumed acquired retinal hemangiomas. Ophthalomology 1983; 90(11): 1292-1300.

27 Damato B. Vasoproliferative retinal tumour. Br J Ophthalmol 2006; 90(4): 399-400. 